Marquette University

e-Publications@Marquette

Biological Sciences Faculty Research and

Publications

Biological Sciences, Department of

$1-2020$

\title{
Edaphic Factors and Initial Conditions Influence Successional Trajectories of Early Regenerating Tropical Dry Forests
}

\author{
Sergio Estrada Villegas \\ Marquette University \\ Mario Bailón \\ Smithsonian Tropical Research Institute \\ Jefferson S. Hall \\ Smithsonian Tropical Research Institute \\ Stefan A. Schnitzer \\ Marquette University, stefan.schnitzer@marquette.edu \\ Benjamin L. Turner \\ Smithsonian Tropical Research Institute
}

See next page for additional authors

Follow this and additional works at: https://epublications.marquette.edu/bio_fac

Part of the Biology Commons

\section{Recommended Citation}

Estrada Villegas, Sergio; Bailón, Mario; Hall, Jefferson S.; Schnitzer, Stefan A.; Turner, Benjamin L.; Caughlin, Trevor; and van Breugel, Michiel, "Edaphic Factors and Initial Conditions Influence Successional Trajectories of Early Regenerating Tropical Dry Forests" (2020). Biological Sciences Faculty Research and Publications. 805.

https://epublications.marquette.edu/bio_fac/805 


\section{Authors}

Sergio Estrada Villegas, Mario Bailón, Jefferson S. Hall, Stefan A. Schnitzer, Benjamin L. Turner, Trevor Caughlin, and Michiel van Breugel

This article is available at e-Publications@Marquette: https://epublications.marquette.edu/bio_fac/805 
Marquette University

e-Publications@Marquette

\section{Biological Sciences Faculty Research and Publications/College of Arts and Sciences}

This paper is NOT THE PUBLISHED VERSION; but the author's final, peer-reviewed manuscript. The published version may be accessed by following the link in the citation below.

Journal of Ecology, Vol. 108, No. 1 (January 2020): 160-174. DOI. This article is @ British Ecological Society and permission has been granted for this version to appear in e-Publications@Marquette. British Ecological Society does not grant permission for this article to be further copied/distributed or hosted elsewhere without the express permission from British Ecological Society.

\section{Edaphic Factors and Initial Conditions Influence Successional Trajectories of Early Regenerating Tropical Dry Forests}

Sergio Estrada-Villegas

Department of Biological Sciences, Marquette University, Milwaukee, WI

Smithsonian Tropical Research Institute, Panama, Panama

Mario Bailón

Smithsonian Tropical Research Institute, Panama, Panama

Jefferson S. Hall

Smithsonian Tropical Research Institute, ForestGEO, Panama, Panama

Stefan A. Schnitzer

Department of Biological Sciences, Marquette University, Milwaukee, WI

Smithsonian Tropical Research Institute, Panama, Panama

Benjamin L. Turner

Smithsonian Tropical Research Institute, Panama, Panama

Trevor Caughlin 
Biological Sciences, Boise State University, Boise, ID

Michiel van Breugel

Smithsonian Tropical Research Institute, ForestGEO, Panama, Panama

Yale-NUS College, Singapore

Department of Biological Sciences, National University of Singapore, Singapore

\section{Abstract}

1. Edaphic factors and initial conditions can regulate the speed of forest succession. Edaphic factors, which include soil chemistry and topography, determine soil resource availability and can filter species as forests mature. Initial plant cover early in succession can determine the rates at which secondary forests change in structure, richness, biomass and composition over time. While some of the effects of edaphic factors and initial conditions on forest succession have been studied, how they simultaneously modify young regenerating tropical forest has rarely been examined.

2. We surveyed 22 young forests plots in Panama for 7 years $(11,6$ and 3 -year-old stands when censuses began). We study how tree and liana species composition change early in succession, as well as how edaphic factors (soil nutrients and topography) and initial conditions (initial basal area and forest canopy cover) influence changes in tree and liana abundance, species richness, biomass and composition throughout succession.

3. We found that edaphic factors and initial conditions explained up to $45 \%$ of the variation in the successional trajectories for trees and lianas. Soil nutrients had a significant positive effect on the changes in tree biomass accretion, while topography significantly contributed to community similarity of large lianas over time. Initial basal area had a significant negative effect on the changes in sapling abundance and tree richness over time and a positive marginal effect on tree biomass accretion. Forest canopy cover only had a positive marginal effect on changes in sapling abundance.

4. Tree abundance, biomass and richness increased over time, while sapling abundance, biomass and richness remained stable or decreased, probably due to community thinning. However, changes over time of small and large lianas diverged, probably due to differential resource availability that affected lianas but not trees.

5. Synthesis. Soil fertility, topography and initial basal area influence early forest regeneration. Higher soil fertility can allow trees to fix carbon faster, and lianas might show habitat association to ridges and slopes. Basal area can determine how fast saplings and trees change in abundance, richness and biomass over time by possibly affecting space availability for recruitment and light availability for growth.

\section{INTRODUCTION}

One of the main goals in forest ecology is to understand the main drivers that shape successional trajectories (Meiners, Cadotte, Fridley, Pickett, \& Walker, 2015). Edaphic factors, which include soil chemistry, soil texture and topography, may have strong and deterministic effects on community composition. Availability of different levels of soil resources can filter out species as communities assemble throughout succession, creating predictable changes in forest composition (Powers \& Marín-Spiotta, 2017). Initial conditions represent the amount of vegetation present across sites during early stages of forest succession (Donato, Campbell, \& Franklin, 2012; Parker \& Pickett, 1998; Phillips, 2004). Initial conditions across sites can influence succession in contrasting ways compared to edaphic conditions, especially if sites are abandoned at similar times. For example, initial conditions such as vegetation remnants can speed community recovery via seed dispersal or facilitation regardless of the edaphic conditions across sites (Moran et al., 2000; Pickett, Cadenasso, \& 
Bartha, 2001). Given that both edaphic factors and initial conditions may be important drivers in the successional dynamics of secondary forests, incorporating both of these factors into models of forest succession is critical to accurately predict how rates of forest recovery vary across secondary forests (Norden et al., 2015). Understanding how forests recover after anthropogenic disturbance is especially urgent as half of all tropical forests are undergoing early or intermediate stages of succession after human alterations (Chazdon et al., 2016).

A wide range of data indicates that edaphic factors exert a deterministic effect on plant communities early in forest succession (Powers \& Marín-Spiotta, 2017). For example, nutrient addition experiments indicate that edaphic factors influence tree communities in successional forests; addition of $\mathrm{N}$ and $\mathrm{P}$ increased plant growth (Davidson et al., 2004), seedling richness and survival (Ceccon, Huante, \& Campo, 2003), and can shift species composition by favouring a subset of species (Siddique et al., 2010). However, observational studies show that the effects of soil nutrients depend on which community properties and which nutrients are analysed. For example, Ayala-Orozco et al. (2017) showed that total $\mathrm{N}$ and $\mathrm{P}$ did not affect changes in basal area or species richness in an early successional tropical dry forest in Mexico, but that richness was positively related to ammonium and nitrate concentrations. Lu, Moran, and Mausel (2002) showed that higher available N concentrations on Alfisols positively affected forest biomass accumulation in early successional forests in Brazil, but that this effect was not present on Oxisols and Ultisols. In successional dry forests in Costa Rica, variation in soil chemistry and texture explained a substantial portion of species' occurrences and distribution (Powers, Becknell, Irving, \& Pèrez-Aviles, 2009; Werden, Becknell, \& Powers, 2018), but the relationship between soil properties and above-ground biomass was weak (Becknell \& Powers, 2014). At a regional scale, above-ground biomass of secondary forests across the Neotropics does not seem to be related to soil cation exchange capacity (Poorter et al., 2016). These results indicate that the direction and magnitude of the effects of edaphic factors depend on how sites differ in soil chemistry, which community property is studied and the spatial scale of the study.

Topography is also expected to have a predicable effect in structuring forests undergoing succession (Scatena \& Lugo, 1995). In old growth forests, topography affects soil formation, soil water content and nutrient concentration (Jenny, 1994), which in turn determines the abundance of about 30 species in a tropical lowland community (Clark, Palmer, \& Clark, 1999). A similar relationship has been found on early successional forests, where topography affects nutrient concentrations (e.g. P and $\mathrm{Mg}$ ), which then affect community composition between upslope plots versus downslope plots (van Breugel et al., 2019). Other aspects of young successional forests are affected by topography. For example, stands located in valleys or troughs tend to regenerate more rapidly, presumably because they have higher soil moisture and higher soil nutrients compared to slopes and ridges (Griscom \& Ashton, 2011). Ridges have better drained soils and nutrients leach downslope from the ridges and may accumulate in the valleys (Jenny, 1994; Scatena \& Lugo, 1995), thus increasing tree growth in the valleys (Scholten et al., 2017). As soil conditions differ along slopes, different species colonize at different rates according to the grade of the slope. For example, Herrera and Finegan (1997) found that Vochysia ferruginea was more abundant in steeper slopes whereas Cordia alliodora was more abundant in gentler slopes across 36 successional forests in Costa Rica. Additionally, regenerating forests on the steeper slopes also tended to be less species rich compared to the successional forest on the gentler slopes (Finegan \& Delgado, 2000). Topography not only covaries with soil chemistry, it can also covary with initial conditions. For example, intermediate or steep slopes can harbour older patches of forests because they tend to be less easily farmed (Crk, Uriarte, Corsi, \& Flynn, 2009). Also, farmers may also protect forest canopy cover along riparian corridors in the valleys, thus providing a rich propagule source for forest regeneration (Griscom, Griscom, \& Ashton, 2009). In sum, both soil nutrients and topography can affect the structure and trajectories of successional communities, but their covariation and their effects on young successional forests remains poorly understood (Griscom \& Ashton, 2011). 
Initial conditions in terms of basal area and forest canopy cover can vary many fold across young sites of similar age, and they are expected to affect the rates of change of forest structure and composition during regeneration (Donato et al., 2012; Phillips, 2004). For example, Guariguata and Ostertag (2001) reviewed six different datasets of young successional tropical forests ( $<20$ years) and showed that basal area varied about $440 \%$ across contemporary sites. Such variation can be due to plant differential growth rates among sites, but also due to drastic variation in the number and spatial distributions of tree spared by farmers, either isolated trees across pastures or narrow forest strips on troughs (Griscom \& Ashton, 2011; Manning, Fischer, \& Lindenmayer, 2006; Tarbox, Fiestas, \& Caughlin, 2018). Sites with different levels of initial conditions should also undergo succession at different rates (Martínez-Ramos \& García-Orth, 2007; Martínez-Ramos et al., 2016; Pickett \& Cadenasso, 2005; Watt, 1947). For example, young sites with higher basal area tend to accumulate biomass at a faster rate compared to sites of similar age but with lower basal area (Babst, Bouriaud, Alexander, Trouet, \& Frank, 2014; Lockett \& Goodwin, 1999). Moreover, initial conditions in terms of forest canopy cover (i.e. isolated trees or riparian forests) across sites of similar age may affect successional trajectories because forest canopy cover increases propagule availability and may speed up species turnover (Griscom et al., 2009; Thomlinson, Serrano, Lopez, Aide, \& Zimmerman, 1996; but see Holl, Reid, Chaves-Fallas, Oviedo-Brenes, \& Zahawi, 2017). For example, the presence of spared trees that fruit abundantly can accelerate succession because they attract a variety of seed dispersers (Medellin \& Gaona, 1999), and the community recruiting underneath their canopy tends to be richer than nearby sites away from the canopy (Sandor \& Chazdon, 2014). Therefore, initial conditions can have a pivotal role on how regenerating forests change in structure, species richness, composition and biomass during regeneration (Norden et al., 2015).

We tested whether edaphic factors and initial conditions could explain the variation in forest dynamics of early secondary forests in a human-modified landscape. We conducted the study in a series of tropical dry forests of similar ages. Tropical dry forests are one of the most threatened ecosystems world-wide due to high rates of historic deforestation (Banda-R et al., 2016). While old growth dry forests are still being deforested (Aide et al., 2013), large areas of farmland in former dry forests are undergoing early stages of succession in some regions across the Neotropics (Caughlin, Rifai, Graves, Asner, \& Bohlman, 2016; Rudel, 2012). Determining whether edaphic factors and initial conditions influence the trajectories of young successional dry forests can help refine which specific drivers accelerate or suppress forest regeneration. Moreover, assessing the relative importance of edaphic factors and initial conditions may support land-use management policies, forest restoration practices and conservation planning in heavily human-modified landscapes.

In this study, we first describe the trajectories of change of forest structure, richness, biomass and composition during 6 lapse years of succession in 22 young regenerating dry forests plots that range from 9 to 17 years after abandonment. We then describe the trajectories of species composition as these forests age. Second, we test whether edaphic factors and initial conditions are significant drivers of change in forest structure, species richness, biomass and composition. We predicted that both edaphic factors and initial conditions would alter forest succession, but in different ways. Forest stands with more available nutrients and gentler slopes should experience faster increases in species richness and plant biomass, as well as faster changes in community composition, because gentler slopes accumulate more nutrients and retain more soil moisture (Jenny, 1994). Gentler slopes and more nutrients should enhance the establishment of species unable to tolerate dryer conditions on ridges or infertile conditions on ridges or steeper slopes. Additionally, young stands with higher initial conditions should show faster increases in species richness and plant biomass because sites with more basal area have larger trees with more foliage to fix carbon and sites with more forest canopy cover may facilitate the establishment of new species that in turn favour community turnover (Lebrija-Trejos, Pérez-García, Meave, Bongers, \& Poorter, 2010; Lohbeck et al., 2013). However, stands with lower initial conditions (i.e. lower basal area) can undergo even faster rates of change in structure, richness, biomass and composition compared to sites with high initial conditions because lower basal area and lower forest canopy cover can reflect more free 
space for recruitment and less competition for space in the canopy, which can both lead to faster biomass accumulation.

\section{MATERIALS AND METHODS}

\subsection{Study site}

Our study was conducted in the municipality of Pedasi, province of Los Santos, Panama $\left(7^{\circ} 25^{\prime} 30^{\prime \prime} \mathrm{N}\right.$; $80^{\circ} 10^{\prime} 30^{\prime \prime} \mathrm{W}$ ). The forests in this region are classified as tropical dry (Holdridge, 1964). The mean annual precipitation in this area is 1,706 mm (Empresa de Transmisión Eléctrica S.A., Cañas Station, 1976-2017). The dry season is typically from December to May. Mean annual temperature of this area is 25ㄷ (Griscom, Connelly, Ashton, Wishnie, \& Deago, 2011). The landscape ranges in elevation from 10 to $100 \mathrm{~m}$. The land was cleared in the 1940s and 1950s for cattle ranching, and conversion of forest to ranching accelerated in 1978 (Griscom et al., 2009). However, cattle farming was reduced from 2000 to 2010, leading to $4 \%$ net forest gain in the region during this decade (Caughlin et al., 2016). Cattle pastures are the dominant land use across the province, but parcels are also used for small-scale tourism and environmental restoration initiatives.

\subsection{Plot selection and data collection}

We chose three areas that had the same land use type before and after pasture abandonment. The areas were logged in the 1960s and 1970s, underwent prescribed burnings for cattle farming (Heckadom-Moreno, 1984) and were abandoned between 2004 and 2007. In one area, pastures were abandoned in 1999. Therefore, the areas had 6, 3, and 11 years old, respectively, at the onset of our study (2010). As in other dry forests in Central America, a few large trees (e.g. Enterolobium cyclocarpum) were spared in the pastures to provide shade for cattle (Griscom et al., 2011). The 11 sites we chose in all three areas are representative of young forests regenerating on abandoned pastures. From our interviews with land owners, the sites have not been disturbed (e.g. fires) and have not been used for cattle ranching since they were abandoned. The distance among areas ranges from $300 \mathrm{~m}$ to $4.2 \mathrm{~km}$, the distance among sites ranges between $160 \mathrm{~m}$ and $4.8 \mathrm{~km}$.

We sampled the forest at each site with two plots $(50 \times 20 \mathrm{~m})$ that were located perpendicular to the slope. This sampling scheme allowed us to account for the effect of topography (i.e. ridges or adjacent to valleys) in forest structure (van Breugel et al., 2013). In each plot, we tagged, measured, and identified to species all trees and shrubs $\geq 5 \mathrm{~cm}$ diameter at breast height (DBH), and lianas $\geq 1 \mathrm{~cm}$ diameter of. We measured tree DBH at $1.3 \mathrm{~m}$ from the ground for trees, while lianas were measured $1.3 \mathrm{~m}$ from the roots, following the protocols suggested by (Schnitzer, Rutishauser, \& Aguilar, 2008). We also tagged, measured and identified all trees and shrubs with a DBH between 1 and $5 \mathrm{~cm}$ in one half of each plot. For convenience, we refer to these smaller trees and shrubs as "saplings" and trees with DBH $>5 \mathrm{~cm}$ as "trees". We refer to all woody climbing plants as "lianas" and refer to "small lianas" as those with a diameter 1-3 cm and "large lianas" as those with a diameter $>3 \mathrm{~cm}$. We used these thresholds because lianas larger than $3 \mathrm{~cm}$ in diameter usually have already reached the forest canopy, whereas those smaller than $3 \mathrm{~cm}$ usually have not managed to reach the forest canopy (Kurzel, Schnitzer, \& Carson, 2006). We conducted full forest inventories (seven) on every plot once per year from 2010 to 2016. Across all plots, we measured 3,512 saplings, 1,787 trees, 2,100 small lianas and 464 large lianas during the 7 years of sampling. We identified $>98 \%$ of individuals to species. Finally, in each plot we bulked three soil samples at $15 \mathrm{~cm}$ depth per plot and extracted base cations ( $\mathrm{Al}, \mathrm{B}, \mathrm{Ca}, \mathrm{Cu}, \mathrm{Fe}, \mathrm{K}, \mathrm{Mg}, \mathrm{Mn}, \mathrm{Zn}$, Table 1) and P using Mehlich-III solution (Mehlich, 1984), with detection using inductively-coupled plasma optical emission spectrometry (ICP-OES) on an Optima 7300 DV (Perkin Elmer, Inc).

Table 1. Mean soil nutrient concentration for 22 forest plots of early successional dry forests in Panama, and Pearson correlations between soil nutrients and two soil fertility axes calculated using nonmetric multidimensional scaling 


\begin{tabular}{|l|l|l|l|l|}
\hline Nutrient & Mean & SE & NMDS 1 & NMDS 2 \\
\hline $\mathrm{C}$ & 3.11 & 0.0789 & -0.062 & 0.04 \\
\hline $\mathrm{N}$ & 0.244 & 0.00606 & -0.038 & -0.001 \\
\hline $\mathrm{P}$ & 2.42 & 0.231 & -0.662 & -0.215 \\
\hline $\mathrm{Al}$ & 918 & 13.9 & 0.474 & -0.219 \\
\hline $\mathrm{B}$ & 0.23 & 0.0268 & -0.021 & 0.044 \\
\hline $\mathrm{Ca}$ & 5,386 & 111 & -0.999 & -0.007 \\
\hline $\mathrm{Cu}$ & 5.96 & 0.348 & -0.079 & -0.484 \\
\hline $\mathrm{Fe}$ & 129 & 3.3 & -0.289 & 0.316 \\
\hline $\mathrm{K}$ & 57.9 & 5.58 & 0.17 & 0.048 \\
\hline $\mathrm{Mg}$ & 1,315 & 32.1 & -0.071 & 0.997 \\
\hline $\mathrm{Mn}$ & 68.9 & 4.66 & -0.063 & -0.055 \\
\hline $\mathrm{Zn}$ & 1.18 & 0.0818 & -0.083 & -0.334 \\
\hline
\end{tabular}

Note

Units for cations and $\mathrm{P}$ are in $\mathrm{mg} / \mathrm{kg} ; \mathrm{C}$ and $\mathrm{N} \%$.

Abbreviation: $S E=$ standard error.

\subsection{Data analysis}

\subsubsection{Description of successional trajectories}

We first assessed changes in abundance, species richness, composition and biomass as basal area increases during our sampling period. We calculated these changes separately for saplings, trees, small lianas and large lianas. We calculated basal area per hectare, diversity as species richness (i.e. Hill number 0 ) and changes in compositional similarity between censuses with the Horn index. Even though tree basal area and tree biomass are usually correlated because DBH is used to calculate both, we opted to use forest basal area to compare among plots, life-forms and size classes because basal area is a reliable indicator of stand performance in terms of tree growth, recruitment and mortality (van Breugel, Martínez-Ramos, \& Bongers, 2006). Moreover, basal area is an adequate proxy for forest age as it has been recently shown to compare dry forest stands (LebrijaTrejos, Pérez-García, et al., 2010; Lohbeck et al., 2013) and basal area is expected to have a differential effect on saplings and lianas because sapling density declines whereas liana densities can remain high as succession progresses (Barry, Schnitzer, van Breugel, \& Hall, 2015). We calculated the Horn index for effective number of species (Jost, Chao, \& Chazdon, 2011) as implemented in the package "vegetarian" for R (Charney \& Record, 2009) because the Horn index is density invariant, replication invariant and monotonic (Jost et al., 2011). Finally, we calculated biomass per stem for saplings and trees with a global multispecies allometric equation that accounts for bioclimatic stress (Chave et al., 2014), which we calculated with local climatological data. We calculated biomass for small and large lianas using a regional multispecies allometric equation (Schnitzer, DeWalt, \& Chave, 2006).

\subsection{Changes in species composition over time}

We first tested whether trajectories of species composition became more similar over time, and whether changes in compositional similarity showed directionality. Assessing directionality quantitatively helped us elucidate how composition changed over time before testing whether edaphic factors and initial conditions affected composition. We first calculated Horn similarity indices for all plots between each census for saplings, trees, small lianas and large lianas, and then calculated ordinations using nonmetric multidimensional scaling (NMDS). To test whether compositional similarity across plots changed significantly from 2010 to 2016, we used a Procrustes analysis, calculated with Gouer's statistic $m^{2}$, and tested the significance of $m^{2}$ with a permutation test (Jackson, 1995). The Procrustes analysis looks for the best fit between two matrices (NMDS of 2010 and 2016) by transforming one matrix with respect to the other. Smaller $m^{2}$ means that two matrices are highly 
similar, and $p<.05$ indicate that high similarity is greater than expected by chance (Lisboa et al., 2014). To detect directionality, we plotted the trajectories for each forest plot with two NMDS axes to visualize how species composition changed through the first years of succession (Feeley, Davies, Perez, Hubbell, \& Foster, 2011). If there were directional changes in species composition, we expected a non-random direction of change from census to census per plot. Thus, we calculated the mean direction of change between censuses for each NMDS axis and used bootstrapping $(10,000$ resamples) to calculate $95 \% \mathrm{Cl}$ around the mean direction of change in composition; if the $95 \% \mathrm{Cl}$ did not overlap with zero, species composition would show directionality (Feeley et al., 2011). To calculate ordinations, we used the function "metaMDS" implemented in the package "vegan" for R, with Wisconsin standardization and square root transformation of the Horn dissimilarity data (Oksanen et al., 2011). To perform the Procrustes analysis, we used PROTEST (Jackson, 1995) as implemented in "vegan". To calculate bootstraps, we used the package "boot" (Canty \& Ripley, 2016).

To visualize which species showed the greatest changes in abundance, we plotted the natural logarithm of species abundances in the initial census versus the natural logarithm of species abundances in the last census. We also plotted the percent change from the initial to the last census for species with an abundance greater than 35 individuals for saplings and small lianas and species with more than 20 individuals for trees and larger lianas (Supporting Information S1-S4). We tested whether abundance between the first and last census across plots were significantly different with a paired $t$ test.

\subsubsection{Effect of edaphic factors and initial conditions on successional trajectories}

We used linear mixed effects models (LMM) to determine whether edaphic factors and initial conditions explained the trajectories of change in forest structure, richness, biomass and composition. For edaphic factors, we used one topographic variable and two axes of soil inorganic nutrients. To select one topographic variable for our models, we first estimated elevation, slope, aspect, Terrain Roughness Index (TRI) and Topographic Position Index (TPI) for each plot using a digital elevation model (Farr et al., 2007). TRI is the sum change in elevation between a grid cell and eight cells around it, with $0 \mathrm{~m}$ being minimum roughness. TPI measures the relative topographic position of a cell as the difference between the elevation of that cell and the mean elevation of a predetermined neighbourhood of cells (De Reu et al., 2013; Riley, DeGloria, \& Elliot, 1999). We then preselected the topographic variable that best fitted our data using a "scale of effect" analysis by comparing Akaike Information Criterion values from LMM using all the initial condition variables (see below) for each response variables (e.g. abundance) per life-form and size class, but tested one topographic variable at a time (Crouzeilles \& Curran, 2016). To do so we used the function "Ime" implemented in the package "nlme" (Pinheiro, Bates, DebRoy, \& Sarkar, 2018). For random factors, we nested plots within sites and accounted the temporal autocorrelation of our data using the covariance structure corAR1 given that our censuses were performed on regular intervals (Gałecki \& Burzykowski, 2013). Fixed factors were standardized by dividing each variable by twice its standard deviations (Gelman, 2008). The two axes of soil inorganic nutrients were calculated from measurements of $\mathrm{Al}, \mathrm{B}, \mathrm{C}, \mathrm{Ca}, \mathrm{Cu}, \mathrm{Fe}, \mathrm{K}, \mathrm{Mg}, \mathrm{Mn}, \mathrm{N}, \mathrm{P}$ and $\mathrm{Zn}$ with an NMDS (Table 1 ) using the Horn index (stress $=0.109$, linear fit $R^{2}=0.95$ ) (see Supporting Information $\mathbf{S 5}$ to see variability of soil nutrients across sites).

We used two explanatory variables to quantify initial conditions; initial plot basal area (basal area in the first census) and forest canopy cover in 1998. Basal area was the sum of the basal area of all woody stems (lianas and trees) expressed on a per ha basis. Forest canopy cover was calculated as the average tree cover within and around each plot across five radii $(30 \mathrm{~m}, 50 \mathrm{~m}, 75 \mathrm{~m}, 100 \mathrm{~m}, 300 \mathrm{~m})$ from the edge of the plot. We measured tree cover by digitizing high resolution aerial photos acquired in 1998 (Tarbox et al., 2018). Initial basal area is a good proxy for initial conditions because basal area integrates the effect of age and initial spatial heterogeneity in vegetation cover across contemporary sites (Donato et al., 2012). More importantly, initial basal area is expected to significantly affect stem size distribution, biomass accumulation and competition intensity (van 
Breugel et al., 2006; Lockett \& Goodwin, 1999; Niklas, Midgley, \& Rand, 2003). By incorporating initial basal area in our analysis, we are in fact accounting for some of the conditions experienced by the stands as they have undergone succession (i.e. high basal area today is probably related to high basal area in the past; Babst et al., 2014; Niklas et al., 2003). To select the forest canopy cover radius that best fitted our data, we ran another "scale of effect" analysis using LMMs with initial basal area for each response variable per life-form and size class, tested one radius of forest canopy cover at a time and selected the model with the lowest AIC. We also used the number of censuses (1-7) as an explanatory variable because we also expected that community properties would change from year to year throughout our study as succession progressed.

Our response variables were the changes in abundance, species richness, biomass and composition between consecutive censuses per life-form and size class (16 total). The changes between consecutive censuses per plot characterize the direction and magnitude of forest succession between censuses. We also calculated changes in composition similarity over time using the Horn index. Before performing LMMs between response and explanatory variables, we performed two preliminary analyses. The first allowed us to discard explanatory variables that were highly collinear $(>0.8)$ and determine whether initial conditions reflected the differences in forest age (Supporting Information S6). Given that initial basal area was correlated with forest age, we retained initial basal area as an explanatory variable for the rest of the analyses. The second preliminary analysis allowed us to explore the relationships between explanatory and response variables as static data by averaging the changes in community properties across censuses. By plotting the average changes of all response variables against initial basal area and forest canopy cover, we had a better understanding of our dataset before analysing the dynamic data (i.e. rates of change between consecutive censuses; Supporting Information S7 and S8).

Finally, we determined how much variation was explained by edaphic factors and initial conditions on the change of abundance, richness, biomass and composition by calculating LMMs. For each model, we used three edaphic factors (one topographic and two soil axes), two initial conditions (initial basal area and forest canopy cover) and censuses as fixed effects, and plots nested within sites plus the temporal autocorrelation structure as random effects. We calculated the variances explained by each model (16 in total) using marginal and conditional coefficients of determination for generalized mixed-effect models with the function r.squaredGLMM, as implemented in the package "MuMIn" (Bartoń, 2013). We standardized each explanatory variable (Gelman, 2008) to compare the magnitude of the effects of significant fixed factors to the response variables. To determine whether a fixed variable in the model had a significant effect on abundance, species richness, composition and biomass for each life-form and size class, we plotted the estimated coefficient from the $\mathrm{LMM}$ and their $95 \% \mathrm{Cl}$.

\section{RESULTS}

The observed trajectories indicate that while abundance, richness and biomass of large trees increased, the abundance and richness of saplings tended to decrease while their biomass remained fairly constant (Figure 1a,b,e,f,i,j). By contrast, abundance and biomass of both small and large lianas increased or stayed the same over the course of succession (Figure $1 c, d, g, h, k, I)$. The abundance and biomass of saplings and large lianas appeared to diverge during succession, indicating an increase in variation across plots (Figure 1a,d). Community composition showed some variation among plots, especially for trees and large lianas, but similarity was overall high across all plots for all life-forms and size classes (Figure $1 \mathrm{~m}, \mathrm{n}, \mathrm{o}, \mathrm{p}$ ). 


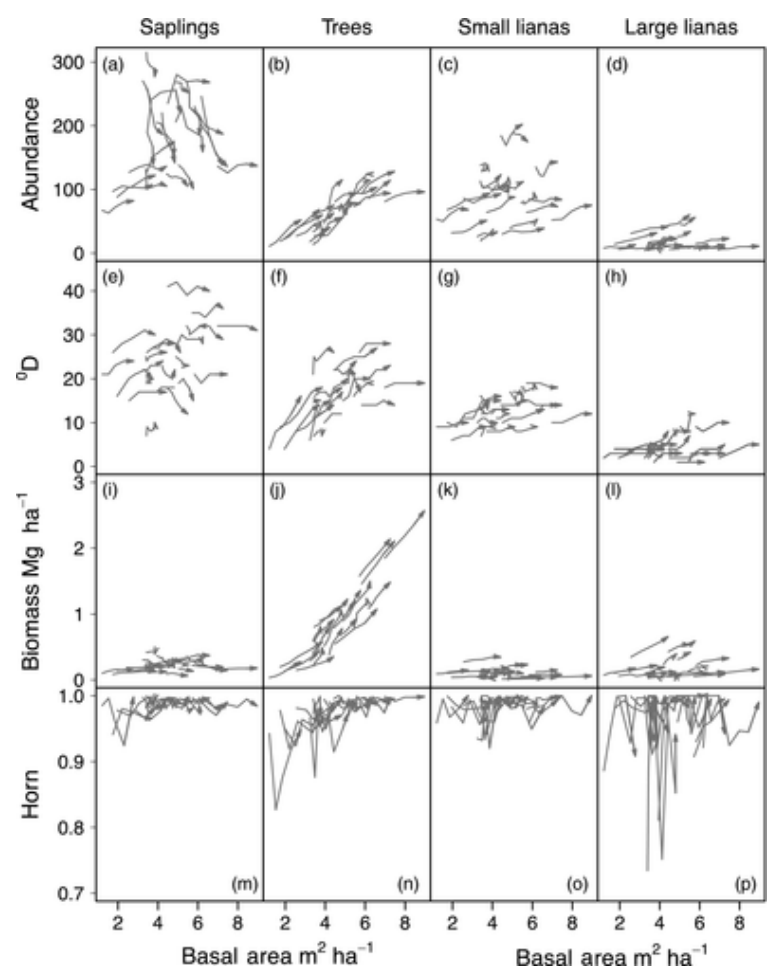

Figure 1 Trajectories of early forest succession for saplings $(1-5 \mathrm{~cm} \mathrm{DBH})$, trees $(>5 \mathrm{~cm} \mathrm{DBH})$, small lianas (1$3 \mathrm{~cm} \mathrm{DBH}$ ) and large lianas (>3 cm DBH) in a dry forest in Panama. Abundance (a-d), species richness (i.e. $\left.{ }^{0} \mathrm{D}\right)$ (e$h$ ), biomass ( $i-l)$ and changes in species composition $(m-p)$ between censuses (Horn index) are plotted against forest basal area

Changes in composition were not directional; bootstrapping analyses showed that mean rate of change among the NMDS axes of species composition between consecutive censuses was not significantly different from zero for all life-forms and size classes (Supporting Information S9). Consequently, composition across plots did not change in a directional manner in 7 years, not entirely surprising given the short time lapse of our study period. Compositional similarities were statistically significant for all life-forms and size classes (saplings: $m^{2}=0.212, p=.001$; trees: $m^{2}=0.487, p=.001$; small lianas: $m^{2}=0.464, p=.001$; large lianas: $\left.m^{2}=0.806 ; p=.024\right)$.

At the species level, the saplings with the greatest increase in abundance from 2010 and 2016 were Cedrela odorata ( $t=-2.472, p=.022)$, Bursera simaruba and Astronium graveolans. The species with the greatest decrease were Lippia americana $(t=2.553, p=.018$ ) and Casearia corymbosa $(t=2.698, p=.013$; Figure 2; Supporting Information S1). For trees, Bauhinia ungulata, Bursera simaruba and Genipa americana showed the greatest increases. L. americana was the only tree species that showed a reduction in abundance across succession ( $t=2.553, p=.018$; Supporting Information S2). The small liana Macroscepis hirsuta showed a marked reduction in abundance, and Bauhinia glabra, Machaerium microphyllum, Chomelia spinosa and Combretum fruticosum increased both as small lianas and as large lianas (Figure 2; Supporting Information S3 and S4). Neither small nor large lianas showed a significant net change in abundance between 2010 and 2016. 


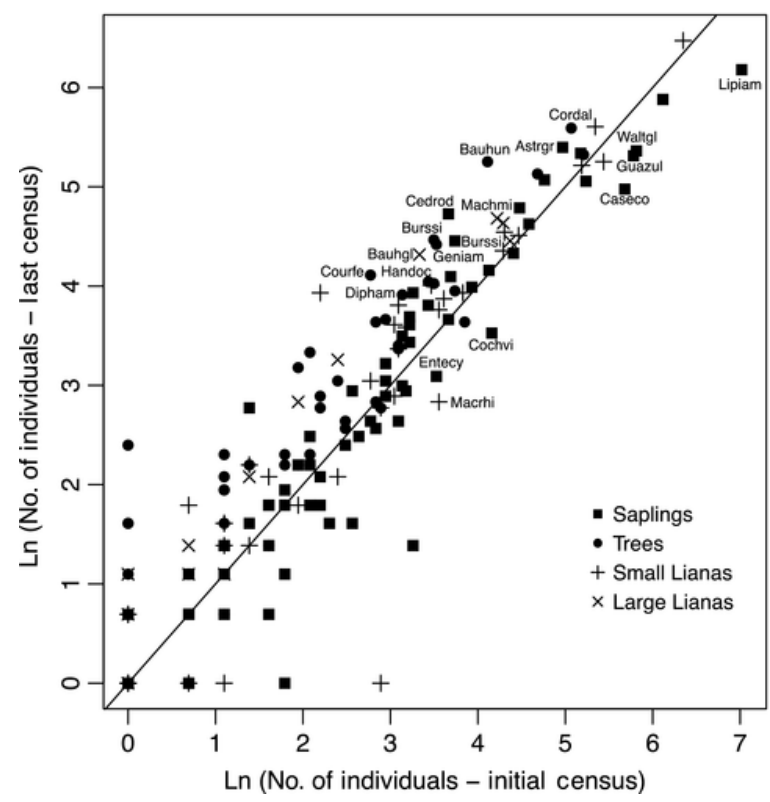

Figure 2 Changes in species abundances of saplings, trees, small lianas and large lianas after 6 years of succession in early regenerating tropical dry forests in Panama. Species further away from the 1:1 line had the greatest change in abundance from the initial to the last census. Ln stands for natural logarithm. Labels correspond to species with an abundance greater than 35 individuals for saplings and small lianas and species with more than 20 individuals for trees and larger lianas. Saplings: Astrgr = Astronium graveolans, Burssi = Bursera simaruba, Caseco = Casearia corymbosa, Cedrod = Cedrela odorata, Cordal = Cordia alliodora, Cochvi = Cochlospermum vitifolium, Entecy = Enterolobium cyclocarpum, Guazul = Guazuma ulmifolia, Lipiam = Lippia americana, Waltgl = Waltheria glomerata . Trees: Bauhun = Bauhinia ungulata, Burssi $=$ Bursera simaruba, Courfe $=$ Coursetia ferruginea, Dipham $=$ Diphysa americana, Geniam = Genipa americana, Handoc $=$ Handroanthus ochraceus. Small lianas: Macrhi $=$ Macroscepis hirsuta . Large lianas: Bauhgl $=$ Bauhinia glabra, Machmi = Machaerium microphyllum

The combination of edaphic factors and initial conditions explained up to $44.7 \%$ of the variance in community properties (Table 2). Edaphic factors and initial conditions (marginal coefficients) explained more of the variation in the changes in abundance, richness and biomass of saplings and trees than for small and large lianas (Table 2). Likewise, changes in compositional similarity (Horn) of saplings and trees were better explained by edaphic factors and initial conditions than for small lianas and large lianas (Table 2).

Table 2. Effects of edaphic factors and initial conditions on the rates of change in four community properties for saplings, trees, small lianas and large lianas in an early successional dry forest in Panama

\begin{tabular}{|l|l|l|l|}
\hline Life-form & Response variable & $R(m)^{2}(\%)$ & $R(c)^{2}(\%)$ \\
\hline Saplings & Structure $(\Delta$ abundance) & 30.6 & 55.1 \\
\hline & Richness $\left(\Delta^{0} \mathrm{D}\right)$ & 18.1 & 21.9 \\
\hline & $\Delta$ Biomass & 26 & 50.9 \\
\hline & Composition (horn) & 23 & 27.7 \\
\hline Trees & Structure ( $\Delta$ abundance) & 7.9 & 9.4 \\
\hline & Richness $\left(\Delta^{0} \mathrm{D}\right)$ & 20.7 & 27.2 \\
\hline & $\Delta$ Biomass & 36.7 & 57.2 \\
\hline & Composition (horn) & 44.7 & 58.7 \\
\hline Small lianas & Structure $(\Delta$ abundance) & 10.8 & 10.8 \\
\hline & Richness $\left(\Delta^{0} \mathrm{D}\right)$ & 6.4 & 10.9 \\
\hline & $\Delta$ Biomass & 5.9 & 19.7 \\
\hline
\end{tabular}




\begin{tabular}{|l|l|l|l|}
\hline & Composition (horn) & 4.9 & 31.9 \\
\hline Large lianas & Structure $(\Delta$ abundance) & 10.9 & 26.6 \\
\hline & Richness $\left(\Delta^{0} \mathrm{D}\right)$ & 6.3 & 6.3 \\
\hline & $\Delta$ Biomass & 7.5 & 61.9 \\
\hline & Composition (horn) & 15.7 & 19.3 \\
\hline
\end{tabular}

Note

$R(m)^{2}$ stands for marginal coefficient, which represents the variance explained by the fixed factors in a linear mixed model. $R(c)^{2}$ stands for conditional coefficient represents the variance explained by fixed and random factors in a linear mixed model. $\Delta$, rates of change; ${ }^{0} \mathrm{D}$, hill number zero.

Initial basal area had a strong and significant negative effect on changes in sapling abundance and tree richness (Figure 3; Supporting Information S7). Initial basal area had a strong significant negative effect on tree composition, and a positive strong effect on tree biomass although marginally significant. Forest canopy cover had a strong positive effect in the abundance of saplings although marginally significant (Figure 3; Supporting Information S8). Edaphic factors, in terms of Soil Axis 1 had a significant positive effect on tree biomass, and Soil Axis 2 had a strong but marginal effect sapling abundance (Figure 3). Topography, in terms of TPI, had a significant positive effect in the composition of large lianas. The effect of census was significant for structure, richness and biomass of saplings and for biomass of large lianas (Figure $\mathbf{3}$ ).

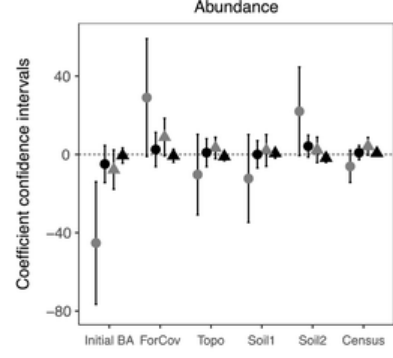

Biomass

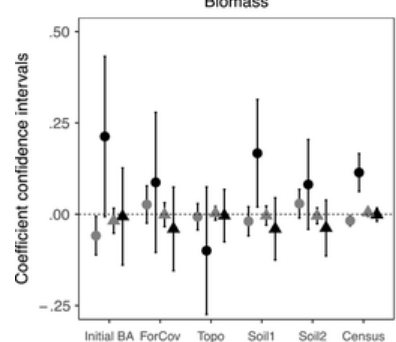

Figure 3 95\% confidence intervals of regression coefficients estimated with linear mixed models using two initial conditions, three edaphic factors and census intervals to explain the change in abundance, richness, biomass and composition across early tropical successional forests in Panama. Saplings = grey circles, trees = black circles, small lianas = grey triangles, and large lianas $=$ black triangles. Initial BA = Initial Basal Area, ForCov $=$ Forest canopy cover inside and around plots. The radius of forest canopy cover was selected for each dataset using linear mixed models (50 m for saplings, $30 \mathrm{~m}$ for trees, $50 \mathrm{~m}$ for small lianas and $50 \mathrm{~m}$ for large lianas). Topo $=$ Topographic inside and around the plots (Elevation for saplings, slope for trees, aspect for small lianas and TPI [Topographic Position Index] for large lianas)

\section{DISCUSSION}

As far as we are aware, our study is the first to assess how trajectories of early successional tropical dry forests are simultaneously affected by edaphic factors and initial conditions for both trees and lianas. We found that edaphic factors and initial conditions affected the variation in the trajectories of community properties of trees 
and lianas in very different ways. Specifically, variation in tree biomass was correlated to soil nutrients, and variation in the composition of large lianas was correlated to TPI. Variation in the abundance and biomass of saplings, and variation of richness and composition of trees was correlated to initial basal area. While the trajectories of saplings and trees seemed to reflect community thinning, the trajectories of small and large lianas seemed to stay the same or diverge as succession progressed.

\subsection{Edaphic factors}

Soil fertility had a significant effect on tree biomass accumulation and a marginal effect on changes in sapling abundance. In old growth forests, soil nutrients have been found to determine species distributions (Hall, McKenna, Ashton, \& Gregoire, 2004), to determine community structure at local scales (Baldeck et al., 2013), to affect growth of both saplings and trees (Turner, Brenes-Arguedas, \& Condit, 2018) and to determine the distribution of tree species at regional scales (Condit, Engelbrecht, Pino, Pérez, \& Turner, 2013). In young secondary forests, soil fertility in terms of $\mathrm{N}$ and $\mathrm{P}$ can have significant effects on plant performance (AyalaOrozco et al., 2017; van Breugel et al., 2019; Lawrence, 2003; Powers \& Marín-Spiotta, 2017). For example, Werden et al. (2018) found that soil chemistry, including P, determined the distribution of 82 species across 84 successional dry forest plots in Costa Rica. Likewise, Davidson et al. (2004) showed that experimental addition of $\mathrm{N}$ significantly increased tree biomass in a young successional moist forests in Brazil. Aside from $\mathrm{N}$ and $\mathrm{P}$, other nutrients seem to play a role in tree biomass accumulation; Santiago-García, Finegan, and Bosque-Pérez (2019) found that $\mathrm{K}$ and $\mathrm{Cu}$ were associated with the variability of tree biomass in young wet regenerating forests in Costa Rica. Our results indicate that Soil Axis 1 represents a gradient of soil nutrients that ranges from high to low $\mathrm{P}$, and from Al to Ca (Table 1). Phosphorus availability affects leaf photosynthetic rates (Reich, Oleksyn, \& Wright, 2009), Ca availability affects cellular respiration and stomatal control (McLaughlin \& Wimmer, 1999) and Al can increase soil pH and preclude nutrient absorption (Lüttge \& Clarkson, 1992). Our results are comparable to what Moran et al. (2000) found in young successional forests in Brazil, where differences in Al and Ca significantly affected changes in tree height across forest plots. Phosphorus and Ca are also key for fine root growth in successional dry forests in Costa Rica (Powers \& Peréz-Aviles, 2013), and root growth directly impacts biomass accumulation (Cairns, Brown, Helmer, \& Baumgardner, 1997). In sum, the variability across studies on which soil nutrients affect successional forests, plus the lack of correlations between our soil fertility axes and other community properties, highlights the difficulty in studying the role of soil nutrients in successional trajectories. Nevertheless, the significant correlation we found indicates a role for soil nutrients in tree biomass accumulation in young tropical dry forests.

Topographic variables explained the changes in species composition of large lianas. The positive correlation between community similarity and TPI indicates that temporal species turnover of large lianas is low on slopes and ridges $(T P I \geq 0)$, whereas turnover is higher in valleys and troughs $(T P I<0)$. The positive correlation between TPI and community similarity may be related to species' specific associations to slopes and ridges. In a moist old growth forest in Panama, Dalling et al. (2012) found that $44 \%$ of all liana species showed habitat preferences, with 26 species showing significant associations with slopes and drier soils. If species are associated with a specific habitat, low temporal turnover could be expected because species tend to recruit, establish and remain in areas (i.e. preferred habitats) where their performance is higher (Feeley et al., 2011; Kanagaraj, Wiegand, Comita, \& Huth, 2011). If that is the case, species turnover of large lianas may be more stable on slopes and ridges in early regenerating dry forests.

Compositional similarity of lianas can also remain high over time if topographic position is related to tree fall gaps. Forest gaps are responsible for the maintenance of liana diversity (Ledo \& Schnitzer, 2014), so if gaps form more often on slopes, as it has been reported by Poorter, Jans, Bongers, and Van Rompaey (2009), gap formation via topography could also explain why liana composition was consistently high on slopes and ridges over time. However, if gap formation was associated with topography, changes in the abundance of saplings or 
small liana should have also been correlated with topography because an influx of resources due to gap formation increases the abundance of saplings and small lianas (Schnitzer \& Carson, 2001). The joint effect of topography and gap formation on the changes in community properties for other life-forms merit further study. Overall, topography has been shown to affect forest succession (Scatena \& Lugo, 1995; Scholten et al., 2017), but variation in topography only seems to be meaningful for large lianas across our young successional plots.

\subsection{Initial conditions}

Initial conditions denote two related drivers across plots undergoing succession. One is the variation in forest canopy cover across contemporary plots at the onset of forest succession and the other is the variation in the amount of area covered by woody plants across plots during succession (Meiners, Pickett, \& Cadenasso, 2015). Both drivers are key to understand forest succession because the first (i.e. forest canopy cover) is linked to abandonment conditions, agricultural history, propagule source and landscape connectivity (Parker \& Pickett, 1998). The second driver (i.e. initial basal area) is linked to competition, stem growth and mortality during or after the formation of a canopy (Chazdon et al., 2007). Therefore, assessing initial conditions in terms of forest canopy cover and initial basal area is vital to determine how initial conditions affect the rates of biomass accumulation and species gain during the first years of succession (Donato et al., 2012; Phillips, 2004).

Our results showed that forest canopy cover at the onset of succession had a positive effect on seedling establishment, although marginally significant. Our results support other studies that have shown that forest canopy cover enhances plant recruitment, perhaps via facilitation or by increasing seed dispersal (Avila-Cabadilla et al., 2012; Derroire, Coe, \& Healey, 2016; Griscom \& Ashton, 2011; Lebrija-Trejos, Meave, Poorter, PérezGarcía, \& Bongers, 2010; Lohbeck et al., 2013; Maza-Villalobos, Balvanera, \& Martínez-Ramos, 2011). Higher forest canopy cover might have increased the abundance of species already present in the riparian corridors around our plots. For example, wind dispersed species, such as Astronium graveolans, Cedrela odorata and Cordia alliodora, which are abundant in the riparian forests in our sites (Griscom et al., 2011) increased in abundance throughout our study (Figure 2). It is possible that forest canopy cover at the onset of succession might contribute to the increase in saplings as succession progresses.

Our results support the prediction that stands with lower initial basal area experience faster changes in plant abundance, richness and biomass, as evidenced by the decreasing rates of change in sapling abundance and biomass and in tree richness (Figure 3; Supporting Information S7). Basal area can be an indicator of competition intensity early in succession because low initial basal area can reflect more space available for recruitment and growth. Conversely, high initial basal area may accelerate sapling mortality and slow sapling biomass accretion because patches with more basal area transpire more water (Berry et al., 2017) probably leaving little soil moisture left for saplings. Moreover, our results resemble what van Breugel et al. (2006) found in a successional forest in Mexico, where mortality via self-thinning was higher than recruitment along a gradient from high initial basal area to low initial basal area. van Breugel et al. (2006) also found that as stands gained recruits and stems increased in size, basal area also increased, but mortality via self-thinning also increased. This gradient in local initial basal area may help explain our results; the decrease in saplings abundance and biomass over time can be due to mortality via self-thinning because more basal area implies more competition for soil moisture.

Furthermore, the decrease in tree richness over time can be due to competition for space in the canopy, because space availability in the canopy diminishes as basal area increases (Lebrija-Trejos, Meave, et al., 2010).

Our results also support the prediction that stands with lower initial basal area can undergo fast rates of change in species composition and biomass accumulation. We found that community similarity increased as initial basal area increased, which is mirrored by the decrease in tree richness (Figure 3; Supporting Information S7). As selfthinning reduces sapling abundance and richness, and as competition delays sapling growth into the next size class, tree species composition becomes more homogeneous. In other words, as initial basal increases, space in 
the canopy becomes more crowed and competition intensifies, making it harder for saplings from different species to grow, reach a space in the forest canopy and contribute to tree species richness. Given that our plots are young, it might take decades for the stem exclusion phase of succession to end and gaps begin to form so saplings of new species are able to growth and join the forest canopy (Chazdon, 2014). The positive marginal effect of high initial basal area on tree biomass accumulation can be explained by the fact that larger trees are able to accumulate biomass at a faster rate than smaller trees (Lockett \& Goodwin, 1999; Stephenson et al., 2014). Contemporary plots with more initial basal can show higher rates of biomass accumulation because larger trees (i.e. higher initial basal) have higher leaf mass and leaf area, which allows them to sequester more carbon per unit of diametric growth (Stephenson et al., 2014).

The amount of basal area early in succession can have crucial implications on successional trajectories because it can set the rate at which the structure, richness and biomass of saplings and trees change over time. Norden et al. (2015) provided an elegant and comprehensive model of tropical forest succession that incorporates the effect of basal area on the changes in structure and diversity. They found that initial basal area early in succession was associated with positive and increasing rates of change in stem density as succession progressed. Contrary to their model, our results show that high initial basal area early in succession decreased the rate of change at which saplings are recruited, sapling biomass is accumulated and species are added to the forest. These apparently contradicting results may be explained by two concomitant processes; at the very onset of succession, initial basal area determines the magnitude of the rates of change at which forests will accumulate individuals, species and biomass. As succession proceeds, basal area will continue to increase but the rates of change, although positive, will decrease in magnitude over time just as Norden et al. (2015) and Lebrija-Trejos, Meave, et al. (2010) have found. As succession continues, basal area saturates, large trees begin to die (Denslow \& Guzman, 2000) and the rates of change of community properties stabilize just as biomass accumulation plateaus (Chazdon et al., 2007). Overall, our results show that the variability of initial conditions, as reflected by different initial basal areas across plots, may affect the rates of change of young successional tropical dry forests (van Breugel et al., 2006; Chazdon et al., 2007; Norden et al., 2015). As succession continues, processes such as competition or niche selective forces will probably override the effects that initial conditions had early in succession (Li et al., 2016).

\subsection{Species-specific changes during early succession}

Changes in the abundance of key tree and liana species seem to be consistent among neotropical dry forests. For example, Astronium graveolans, Bursera simaruba, Cedrela odorata and Handroanthus ochraceus, which increased in our plots, have also been found to increase in abundance in early successional dry forests in Costa Rica (Kalacska et al., 2004), Nicaragua (Marín, Tigabu, González-Rivas, \& Odén, 2009), Brazil (Madeira et al., 2009) and Colombia (Castellanos-Castro \& Newton, 2015). Likewise, Cordia alliodora and Bauhinia ungulata, which also increased in abundance during our study, have been shown to increase during succession in dry forests in Nicaragua (Esquivel, Harvey, Finegan, Casanoves, \& Skarpe, 2008; Marín et al., 2009). Most of these species either have small seeds that are wind dispersed, show high specific leaf area or are deciduous (Engemann et al., 2016; Wright et al., 2010). A combination of these traits are common among tree species in young successional dry forests (Lohbeck et al., 2012). The species that decreased during our study have also been shown to decrease elsewhere. For example, Lippia americana, Guazuma ulmifolia and Cochlospermum vitifolium also decrease in abundance in successional dry forests in Colombia (Castellanos-Castro \& Newton, 2015) and Costa Rica (Kalacska et al., 2004; but see Powers et al., 2009). These three species are light demanding and become quickly out-competed by surrounding taller vegetation (Griscom et al., 2011). The liana species Machaerium microphyllum and Bauhinia glabra, which increased during our study, also increased throughout forest succession in a Colombian dry forest (Castellanos-Castro \& Newton, 2015). Even though we did not find significant changes in composition during 7 years of succession across plots that span 20 years of 
regeneration, species-specific responses to succession coincide across regenerating dry forests in Central and South America. These responses are probably due to species-specific growth rates or leaf traits across the species' geographic distribution.

\subsection{Successional trajectories}

Determining the predictability of forest succession has been a heavily debated topic (Li et al., 2016; Meiners, Cadotte, et al., 2015; Norden et al., 2015; Pickett et al., 2001). Our findings concur with studies that show that tree abundance and especially tree biomass, increase in a predicable fashion early in succession (Derroire, Balvanera, et al., 2016; Dupuy et al., 2012; Kennard, 2002; Lebrija-Trejos, Meave, et al., 2010). However, our results also show important spatial and temporal heterogeneity in successional trajectories among sites of similar age for saplings and for small and large lianas. Such heterogeneity not only reflects that different mechanisms (i.e. niche differentiation, initial conditions, etc.) might be operating simultaneously across the landscape with variable strengths, but it also calls for a nuance approach to better understand the drivers of forest succession across space and time (Arroyo-Rodríguez et al., 2015).

Moreover, no other study, as far as we are aware, has tracked the trajectories of change for structure, species richness, composition and biomass of lianas in early successional dry forests. Other studies in successional moist forests have shown that liana abundance, biomass and richness reach high levels early in succession, but liana density declines after 50-70 years of succession while liana basal area remains high as forests age (Barry et al., 2015; Dewalt, Schnitzer, \& Denslow, 2000; Lai, Hall, Turner, \& van Breugel, 2017). In wetter forests, liana abundance decline, richness remains constant and biomass increases during forest succession (Letcher \& Chazdon, 2009). In drier forests, liana abundance, richness and basal area appear to increase rapidly and then decline as forests age (Madeira et al., 2009). Our results from an early successional dry forest show that liana structure, composition and biomass are heterogeneous and seem less predictable than trajectories for trees. High variability in liana structure and biomass can be related to different degrees of canopy closure among plots; lianas tend to show less recruitment when light availability in the understorey is low, and only lianas that were able to reach the top of the canopy will continue to grow and accumulate biomass (Letcher, 2015). Overall, the direction and magnitude of the trajectories for trees seem predictable and are congruent with other studies, but more detailed studies are needed to determine why large lianas show almost divergent trajectories among plots.

\section{CONCLUSIONS}

We followed the fate of approximately 8,000 trees and lianas for 7 years and concluded that the succession of trees, measured by their abundance, richness and biomass follow a predictable trajectory in tropical dry forests. However, the successional trajectories of lianas in these forests seemed less predictable. More importantly, we found that edaphic factors and initial conditions explained some of the changes in early successional dry forest communities. Edaphic factors were correlated with tree biomass accumulation and with changes in species composition for large lianas. Initial conditions were good predictors of the changes in sapling structure and biomass and trees richness and composition. Low basal area during the first years of succession may allow rapid plant recruitment because more light and space are available. In areas with high initial basal area early, however, the rates of change of sapling abundance, richness and biomass decreased, which suggests a reduction in the speed of establishment and recruitment as succession progresses. Nevertheless, as basal area increases over time, larger trees accumulate more biomass. We propose that initial conditions, although stochastic in nature, can determine the magnitude of the rates at which early successional dry forests will recruit new trees, accumulate new species richness and accrue biomass. As succession proceeds, the rates of change will continue to be positive but will drop in magnitude, and the strong initial effect of initial conditions will diminish over time. 


\section{ACKNOWLEDGEMENTS}

This research was supported by The Grantham Foundation for the Protection of the Environment. We are grateful to the private landowners who allowed us to work on their land. Edwina von Gal and Vernon Scholey provided useful background information and moral support throughout the study. We are grateful to the staff of the Achotines Laboratory of the Inter-American Tropical Tuna Commission (IATCC) and Eco Venao for their generosity during field visits. Research was conducted under a series of research permits issued to J.S.H. by the Ministry of the Environment of Panama. This work could not have been completed without the dedication and hard work by numerous individuals participating in field work over the years. We are particularly grateful to Andres Hernandez, Carlos Diaz, Johana Balbuena, Anabel Rivas, Guillermo Fernandez, Miguel Nunez, Edwin Garcia, and Cristina Barber. S.E.-V. is grateful to Katherine Sinacore and KC Cushman for invaluable help during data analysis. David Deffilipis and edited an early version of the manuscript, Natalia Norden gave valuable comments to the manuscript, Ana Cristina Palma and Beatriz H. Ramirez edited the abstract in Spanish. S.E.-V. has been supported by a fellowship from the Departamento Administrativo de Ciencia, Tecnología e Innovación COLCIENCIAS.

\section{AUTHORS' CONTRIBUTIONS}

S.E.-V. conceived the manuscript. J.S.H and M.v.B. designed the sampling protocols and lead sampling campaigns. M.B., J.S.H, B.L.T., T.C. and M.v.B. collected the data. S.E.-V. analysed the data. S.E.-V, J.S.H., S.A.S., B.L.T., T.C. and M.v.B. wrote the manuscript. All authors contributed critically to the drafts and gave final approval for publication.

\section{DATA AVAILABILITY STATEMENT}

Data used in this study are archived at figshare: https://doi.org/10.6084/m9.figshare.7144112 (Estrada-Villegas et al., 2019).

\section{Supporting Information}

\begin{tabular}{|l|l|}
\hline Filename & Description \\
\hline jec13263-sup-0001-Supinfo.docxapplication/docx, 831.5 KB & \\
\hline
\end{tabular}

Please note: The publisher is not responsible for the content or functionality of any supporting information supplied by the authors. Any queries (other than missing content) should be directed to the corresponding author for the article.

\section{REFERENCES}

Aide, T. M., Clark, M. L., Grau, H. R., López-Carr, D., Levy, M. A., Redo, D., ... Muñiz, M. (2013). Deforestation and reforestation of Latin America and the Caribbean (20012010). Biotropica, 45(2), 262-271. https://doi.org/10.1111/j.1744-7429.2012.00908.x

Arroyo-Rodríguez, V., Melo, F. P. L., Martínez-Ramos, M., Bongers, F., Chazdon, R. L., Meave, J. A., ... Tabarelli, M. (2015). Multiple successional pathways in human-modified tropical landscapes: New insights from forest succession, forest fragmentation and landscape ecology research. Biological Reviews, 92(1), 326- 340. https://doi.org/10.1111/brv.12231

Avila-Cabadilla, L. D., Sanchez-Azofeifa, G. A., Stoner, K. E., Alvarez-Añorve, M. Y., Quesada, M., \& PortilloQuintero, C. A. (2012). Local and Landscape factors determining occurrence of phyllostomid bats in tropical secondary forests. PLOS ONE, 7(4), e35228. https://doi.org/10.1371/journal.pone.0035228

Ayala-Orozco, B., Gavito, M. E., Mora, F., Siddique, I., Balvanera, P., Jaramillo, V. J., ... Martínez-Meyer, E. (2017). Resilience of soil properties to land-use change in a tropical dry forest ecosystem. Land Degradation \& Development, 29(2), 315-325. https://doi.org/10.1002/ldr.2686 
Babst, F., Bouriaud, O., Alexander, R., Trouet, V., \& Frank, D. (2014). Toward consistent measurements of carbon accumulation: A multi-site assessment of biomass and basal area increment across Europe. Dendrochronologia, 32(2), 153- 161. https://doi.org/10.1016/i.dendro.2014.01.002

Baldeck, C. A., Harms, K. E., Yavitt, J. B., John, R., Turner, B. L., Valencia, R., ...Dalling, J. W. (2013). Soil resources and topography shape local tree community structure in tropical forests. Proceedings of the Royal Society B: Biological Sciences, 280(1753), 20122532. https://doi.org/10.1098/rspb.2012.2532

Banda-R, K., Delgado-Salinas, A., Dexter, K. G., Linares-Palomino, R., Oliveira-Filho, A., Prado, D., ... Pennington, R. T. (2016). Plant diversity patterns in neotropical dry forests and their conservation implications. Science, 353(6306), 1383-1387. https://doi.org/10.1126/science.aaf5080

Barry, K. E., Schnitzer, S. A., van Breugel, M., \& Hall, J. S. (2015). Rapid liana colonization along a secondary forest chronosequence. Biotropica, 47(6), 672-680. https://doi.org/10.1111/btp.12259

Bartoń, K. (2013). Package 'MuMIn': multi-model inference. R package version 1.9.13.

Becknell, J. M., \& Powers, J. S. (2014). Stand age and soils as drivers of plant functional traits and aboveground biomass in secondary tropical dry forest. Canadian Journal of Forest Research, 44(6), 604- 613. https://doi.org/10.1139/cjfr-2013-0331

Berry, Z. C., Looker, N., Holwerda, F., Gómez Aguilar, L. R., Ortiz Colin, P., González Martínez, T., \& Asbjornsen, H. (2017). Why size matters: The interactive influences of tree diameter distribution and sap flow parameters on upscaled transpiration. Tree Physiology, 38(2), 263-275. https://doi.org/10.1093/treephys/tpx124

Cairns, M. A., Brown, S., Helmer, E. H., \& Baumgardner, G. A. (1997). Root biomass allocation in the world's upland forests. Oecologia, 111(1), 1- 11. https://doi.org/10.1007/s004420050201

Canty, A., \& Ripley, B. (2016). boot: Bootstrap R (S-Plus) Functions. R package version 1.3-18.

Castellanos-Castro, C., \& Newton, A. C. (2015). Environmental heterogeneity influences successional trajectories in colombian seasonally dry tropical forests. Biotropica, 47(6), 660-671. https://doi.org/10.1111/btp.12245

Caughlin, T. T., Rifai, S. W., Graves, S. J., Asner, G. P., \& Bohlman, S. A. (2016). Integrating LiDAR-derived tree height and Landsat satellite reflectance to estimate forest regrowth in a tropical agricultural landscape. Remote Sensing in Ecology and Conservation, 2(4), 190- 203. https://doi.org/10.1002/rse2.33

Ceccon, E., Huante, P., \& Campo, J. (2003). Effects of nitrogen and phosphorus fertilization on the survival and recruitment of seedlings of dominant tree species in two abandoned tropical dry forests in Yucatán, Mexico. Forest Ecology and Management, 182(1), 387- 402. https://doi.org/10.1016/S0378$1127(03) 00085-9$

Charney, N., \& Record, S. (2009). vegetarian. R package version 1.2.

Chave, J., Réjou-Méchain, M., Búrquez, A., Chidumayo, E., Colgan, M. S., Delitti, W. B. C., ... Vieilledent, G. (2014). Improved allometric models to estimate the aboveground biomass of tropical trees. Global Change Biology, 20(10), 3177- 3190. https://doi.org/10.1111/gcb.12629

Chazdon, R. L. (2014). Second growth: The promise of tropical forest regeneration in an age of deforestation. Chicago, IL: University of Chicago Press.

Chazdon, R. L., Broadbent, E. N., Rozendaal, D. M. A., Bongers, F., Zambrano, A. M. A., Aide, T. M., ... Poorter, L. (2016). Carbon sequestration potential of second-growth forest regeneration in the Latin American tropics. Science Advances, 2(5), e1501639. https://doi.org/10.1126/sciadv.1501639

Chazdon, R. L., Letcher, S. G., van Breugel, M., Martínez-Ramos, M., Bongers, F., \& Finegan, B. (2007). Rates of change in tree communities of secondary Neotropical forests following major disturbances. Philosophical Transactions of the Royal Society B: Biological Sciences, 362(1478), 273-289. https://doi.org/10.1098/rstb.2006.1990

Clark, D. B., Palmer, M. W., \& Clark, D. A. (1999). Edaphic factors and the landscape-scale distributions of tropical rain forest trees. Ecology, 80(8), 2662-2675. https://doi.org/10.1890/00129658(1999)080[2662:EFATLS]2.0.CO;2 
Condit, R., Engelbrecht, B. M. J., Pino, D., Pérez, R., \& Turner, B. L. (2013). Species distributions in response to individual soil nutrients and seasonal drought across a community of tropical trees. Proceedings of the National Academy of Sciences of the United States of America, 110(13), 5064- 5068. https://doi.org/10.1073/pnas.1218042110

Crk, T., Uriarte, M., Corsi, F., \& Flynn, D. (2009). Forest recovery in a tropical landscape: What is the relative importance of biophysical, socioeconomic, and landscape variables? Landscape Ecology, 24(5), 629- 642. https://doi.org/10.1007/s10980-009-9338-8

Crouzeilles, R., \& Curran, M. (2016). Which landscape size best predicts the influence of forest cover on restoration success? A global meta-analysis on the scale of effect. Journal of Applied Ecology, 53(2), 440- 448. https://doi.org/10.1111/1365-2664.12590

Dalling, J. W., Schnitzer, S. A., Baldeck, C., Harms, K. E., John, R., Mangan, S. A., ... Hubbell, S. P. (2012). Resourcebased habitat associations in a neotropical liana community. Journal of Ecology, 100(5), 1174-1182. https://doi.org/10.1111/i.1365-2745.2012.01989.x

Davidson, E. A., Reis de Carvalho, C. J., Vieira, I. C. G., Figueiredo, R. D. O., Moutinho, P., Yoko Ishida, F., ... Tuma Sabá, R. (2004). Nitrogen and phosphorus limitation of biomass growth in a tropical secondary forest. Ecological Applications, 14(4), S150- S163. https://doi.org/10.1890/01-6006

De Reu, J., Bourgeois, J., Bats, M., Zwertvaegher, A., Gelorini, V., De Smedt, P., ...Crombé, P. (2013). Application of the topographic position index to heterogeneous landscapes. Geomorphology, 186(Suppl. C), 39- 49. https://doi.org/10.1016/i.geomorph.2012.12.015

Denslow, J. S., \& Guzman, S. (2000). Variation in stand structure, light and seedling abundance across a tropical moist forest chronosequence, Panama. Journal of Vegetation Science, 11(2), 201-212. https://doi.org/10.2307/3236800

Derroire, G., Balvanera, P., Castellanos-Castro, C., Decocq, G., Kennard, D. K., Lebrija-Trejos, E., ... Healey, J. R. (2016). Resilience of tropical dry forests - A meta-analysis of changes in species diversity and composition during secondary succession. Oikos, 125(10), 1386- 1397. https://doi.org/10.1111/oik.03229

Derroire, G., Coe, R., \& Healey, J. R. (2016). Isolated trees as nuclei of regeneration in tropical pastures: Testing the importance of niche-based and landscape factors. Journal of Vegetation Science, 27(4), 679-691. https://doi.org/10.1111/ivs.12404

Dewalt, S. J., Schnitzer, S. A., \& Denslow, J. S. (2000). Density and diversity of lianas along a chronosequence in a central Panamanian lowland forest. Journal of Tropical Ecology, 16(1), 1- 19. https://doi.org/10.1017/S0266467400001231

Donato, D. C., Campbell, J. L., \& Franklin, J. F. (2012). Multiple successional pathways and precocity in forest development: Can some forests be born complex? Journal of Vegetation Science, 23(3), 576- 584. https://doi.org/10.1111/i.1654-1103.2011.01362.x

Dupuy, J. M., Hernández-Stefanoni, J. L., Hernández-Juárez, R. A., Tetetla-Rangel, E., López-Martínez, J. O., Leyequién-Abarca, E., ... May-Pat, F. (2012). Patterns and correlates of tropical dry forest structure and composition in a highly replicated chronosequence in Yucatan, Mexico. Biotropica, 44(2), 151- 162. https://doi.org/10.1111/j.1744-7429.2011.00783.x

Engemann, K., Sandel, B., Boyle, B., Enquist, B. J., Jørgensen, P. M., Kattge, J., ... Svenning, J.-C. (2016). A plant growth form dataset for the New World. Ecology, 97(11), 3243- 3243. https://doi.org/10.1002/ecy.1569

Esquivel, M. J., Harvey, C. A., Finegan, B., Casanoves, F., \& Skarpe, C. (2008). Effects of pasture management on the natural regeneration of neotropical trees. Journal of Applied Ecology, 45(1), 371- 380. https://doi.org/10.1111/j.1365-2664.2007.01411.x

Estrada-Villegas, S., Bailón, M., Hall, J. S., Schnitzer, S. A., Turner, B. L., Caughlin, T., \& van Breugel, M. (2019). Edaphic factors and initial conditions influence successional trajectories of early regenerating tropical dry forests. Figshare, https://doi.org/10.6084/m9.figshare.7144112

Farr, T. G., Rosen, P. A., Caro, E., Crippen, R., Duren, R., Hensley, S., ... Alsdorf, D. (2007). The shuttle radar topography mission. Reviews of Geophysics, 45(2), 1- 33. https://doi.org/10.1029/2005rg000183 
Feeley, K. J., Davies, S. J., Perez, R., Hubbell, S. P., \& Foster, R. B. (2011). Directional changes in the species composition of a tropical forest. Ecology, 92(4), 871-882. https://doi.org/10.1890/10-0724.1

Finegan, B., \& Delgado, D. (2000). Structural and floristic heterogeneity in a 30-year-old Costa Rican rain forest restored on pasture through natural secondary succession. Restoration Ecology, 8(4), 380-393. https://doi.org/10.1046/i.1526-100x.2000.80053.x

Gałecki, A., \& Burzykowski, T. (2013). Linear mixed-effects models using R: A step-by-step approach. New York, NY: Springer Science \& Business Media.

Gelman, A. (2008). Scaling regression inputs by dividing by two standard deviations. Statistics in Medicine, 27(15), 2865- 2873. https://doi.org/10.1002/sim.3107

Griscom, H. P., \& Ashton, M. S. (2011). Restoration of dry tropical forests in Central America: A review of pattern and process. Forest Ecology and Management, 261(10), 1564- 1579. https://doi.org/10.1016/j.foreco.2010.08.027

Griscom, H. P., Connelly, A. B., Ashton, M. S., Wishnie, M. H., \& Deago, J. (2011). The structure and composition of a tropical dry forest landscape after land clearance; Azuero Peninsula, Panama. Journal of Sustainable Forestry, 30(8), 756- 774. https://doi.org/10.1080/10549811.2011.571589

Griscom, H. P., Griscom, B. W., \& Ashton, M. S. (2009). Forest regeneration from pasture in the dry tropics of Panama: Effects of cattle, exotic grass, and forested riparia. Restoration Ecology, 17(1), 117- 126. https://doi.org/10.1111/i.1526-100X.2007.00342.x

Guariguata, M. R., \& Ostertag, R. (2001). Neotropical secondary forest succession: Changes in structural and functional characteristics. Forest Ecology and Management, 148(13), 185- 206. https://doi.org/10.1016/S0378-1127(00)00535-1

Hall, J. S., McKenna, J. J., Ashton, P. M. S., \& Gregoire, T. G. (2004). Habitat characterizations underestimate the role of edaphic factors controlling the distribution of Entandrophragma. Ecology, 85(8), 2171-2183. https://doi.org/10.1890/03-0043

Heckadom-Moreno, S. (1984). Panama's expanding cattle front: The Santeño campesinos and the colonization of the forests. Doctoral dissertation, University of Essex, UK.

Herrera, B., \& Finegan, B. (1997). Substrate conditions, foliar nutrients and the distributions of two canopy tree species in a Costa Rican secondary rain forest. Plant and Soil, 191(2), 259- 267. https://doi.org/10.1023/a:1004209915530

Holdridge, L. R. (1964). Life zone ecology. San José, Costa Rica: Centro Científico Tropical.

Holl, K. D., Reid, J. L., Chaves-Fallas, J. M., Oviedo-Brenes, F., \& Zahawi, R. A. (2017). Local tropical forest restoration strategies affect tree recruitment more strongly than does landscape forest cover. Journal of Applied Ecology, 54(4), 1091- 1099. https://doi.org/10.1111/1365-2664.12814

Jackson, D. A. (1995). PROTEST: A PROcrustean Randomization TEST of community environment concordance. Écoscience, 2(3), 297- 303. https://doi.org/10.1080/11956860.1995.11682297

Jenny, H. (1994). Factors of soil formation: A system of quantitative pedology. New York, NY: McGraw-Hill. Jost, L., Chao, A., \& Chazdon, R. (2011). Compositional similarity and beta diversity. In A. E. Magurran \& B. J. McGill (Eds.), Biological diversity: Frontiers in measurement and assessment (pp. 66-84). Oxford, UK: Oxford University Press.

Kalacska, M., Sanchez-Azofeifa, G. A., Calvo-Alvarado, J. C., Quesada, M., Rivard, B., \& Janzen, D. H. (2004). Species composition, similarity and diversity in three successional stages of a seasonally dry tropical forest. Forest Ecology and Management, 200(1), 227- 247. https://doi.org/10.1016/j.foreco.2004.07.001

Kanagaraj, R., Wiegand, T., Comita, L. S., \& Huth, A. (2011). Tropical tree species assemblages in topographical habitats change in time and with life stage. Journal of Ecology, 99(6), 1441-1452. https://doi.org/10.1111/j.1365-2745.2011.01878.x

Kennard, D. K. (2002). Secondary forest succession in a tropical dry forest: Patterns of development across a 50year chronosequence in lowland Bolivia. Journal of Tropical Ecology, 18(01), 53- 66. https://doi.org/10.1017/S0266467402002031 
Kurzel, B. P., Schnitzer, S. A., \& Carson, W. P. (2006). Predicting liana crown location from stem diameter in three panamanian lowland forests. Biotropica, 38(2), 262- 266. https://doi.org/10.1111/j.17447429.2006.00135.x

Lai, H. R., Hall, J. S., Turner, B. L., \& van Breugel, M. (2017). Liana effects on biomass dynamics strengthen during secondary forest succession. Ecology, 98(4), 1062-1070. https://doi.org/10.1002/ecy.1734

Lawrence, D. (2003). The response of tropical tree seedlings to nutrient supply: Meta-analysis for understanding a changing tropical landscape. Journal of Tropical Ecology, 19(3), 239- 250. https://doi.org/10.1017/S0266467403003274

Lebrija-Trejos, E., Meave, J. A., Poorter, L., Pérez-García, E. A., \& Bongers, F. (2010). Pathways, mechanisms and predictability of vegetation change during tropical dry forest succession. Perspectives in Plant Ecology, Evolution and Systematics, 12(4), 267- 275. https://doi.org/10.1016/j.ppees.2010.09.002

Lebrija-Trejos, E., Pérez-García, E. A., Meave, J. A., Bongers, F., \& Poorter, L. (2010). Functional traits and environmental filtering drive community assembly in a species-rich tropical system. Ecology, 91(2), 386- 398. https://doi.org/10.1890/08-1449.1

Ledo, A., \& Schnitzer, S. A. (2014). Disturbance and clonal reproduction determine liana distribution and maintain liana diversity in a tropical forest. Ecology, 95(8), 2169-2178. https://doi.org/10.1890/131775.1

Letcher, S. G. (2015). Patterns of liana succession in tropical forests. In S. A. Schnitzer, F. Bongers, R. J. Burnham, \& F. E. Putz (Eds.), Ecology of lianas (pp. 116- 130). Oxford, UK: John Wiley \& Sons.

Letcher, S. G., \& Chazdon, R. L. (2009). Lianas and self-supporting plants during tropical forest succession. Forest Ecology and Management, 257(10), 2150-2156. https://doi.org/10.1016/i.foreco.2009.02.028

Li, S.-P., Cadotte, M. W., Meiners, S. J., Pu, Z., Fukami, T., \& Jiang, L. (2016). Convergence and divergence in a long-term old-field succession: The importance of spatial scale and species abundance. Ecology Letters, 19(9), 1101-1109. https://doi.org/10.1111/ele.12647

Lisboa, F. J. G., Peres-Neto, P. R., Chaer, G. M., Jesus, E. D. C., Mitchell, R. J., Chapman, S. J., \& Berbara, R. L. L. (2014). Much beyond mantel: Bringing procrustes association metric to the plant and soil ecologist's toolbox. PLOS ONE, 9(6), e101238. https://doi.org/10.1371/journal.pone.0101238

Lockett, E., \& Goodwin, A. (1999). Effects of initial stocking on stand development in even-aged mixed eucalypt regrowth: A preliminary model. Australian Forestry, 62(1), 9- 16. https://doi.org/10.1080/00049158.1999.10674756

Lohbeck, M., Poorter, L., Lebrija-Trejos, E., Martínez-Ramos, M., Meave, J. A., Paz, H., ... Bongers, F. (2013). Successional changes in functional composition contrast for dry and wet tropical forest. Ecology, 94(6), 1211- 1216. https://doi.org/10.1890/12-1850.1

Lohbeck, M., Poorter, L., Paz, H., Pla, L., van Breugel, M., Martínez-Ramos, M., \& Bongers, F. (2012). Functional diversity changes during tropical forest succession. Perspectives in Plant Ecology, Evolution and Systematics, 14(2), 89-96. https://doi.org/10.1016/j.ppees.2011.10.002

Lu, D., Moran, E., \& Mausel, P. (2002). Linking Amazonian secondary succession forest growth to soil properties. Land Degradation \& Development, 13(4), 331- 343. https://doi.org/10.1002/ldr.516

Lüttge, U., \& Clarkson, D. T. (1992). Mineral nutrition: Aluminium. In H. D. Behnke, K. Esser, K. Kubitzki, M. Runge, \& H. Ziegler (Eds.), Progress in botany: Structural botany physiology genetics taxonomy geobotany / Fortschritte der Botanik Struktur Physiologie Genetik Systematik Geobotanik (pp. 63-77). Berlin, Heidelberg, Germany: Springer.

Madeira, B. G., Espírito-Santo, M. M., Neto, S. D. Â., Nunes, Y. R. F., Arturo Sánchez Azofeifa, G., Wilson Fernandes, G., \& Quesada, M. (2009). Changes in tree and liana communities along a successional gradient in a tropical dry forest in south-eastern Brazil. Plant Ecology, 201(1), 291- 304. https://doi.org/10.1007/s11258-009-9580-9

Manning, A. D., Fischer, J., \& Lindenmayer, D. B. (2006). Scattered trees are keystone structures - Implications for conservation. Biological

Conservation, 132(3), 311-321. https://doi.org/10.1016/j.biocon.2006.04.023 
Marín, G. C., Tigabu, M., González-Rivas, B., \& Odén, P. C. (2009). A chronosequence analysis of forest recovery on abandoned agricultural fields in Nicaragua. Journal of Forestry

Research, 20(3), 213-222. https://doi.org/10.1007/s11676-009-0034-y

Martínez-Ramos, M., \& García-Orth, X. (2007). Sucesión ecológica y restauración de las selvas húmedas. Boletín De La Sociedad Botánica De México, 80(Suplemento), 69- 84.

Martínez-Ramos, M., Pingarroni, A., Rodríguez-Velázquez, J., Toledo-Chelala, L., Zermeño-Hernández, I., \& Bongers, F. (2016). Natural forest regeneration and ecological restoration in human-modified tropical landscapes. Biotropica, 48(6), 745- 757. https://doi.org/10.1111/btp.12382

Maza-Villalobos, S., Balvanera, P., \& Martínez-Ramos, M. (2011). Early regeneration of tropical dry forest from abandoned pastures: Contrasting chronosequence and dynamic approaches. Biotropica, 43(6), 666-675. https://doi.org/10.1111/j.1744-7429.2011.00755.x

McLaughlin, S. B., \& Wimmer, R. (1999). Calcium physiology and terrestrial ecosystem processes. New Phytologist, 142(3), 373-417.

Medellin, R. A., \& Gaona, O. (1999). Seed dispersal by bats and birds in forest and disturbed habitats of Chiapas, Mexico. Biotropica, 31(3), 478-485.

Mehlich, A. (1984). Mehlich 3 soil test extractant: A modification of Mehlich 2 extractant. Communications in Soil Science and Plant Analysis, 15(12), 1409-1416. https://doi.org/10.1080/00103628409367568

Meiners, S. J., Cadotte, M. W., Fridley, J. D., Pickett, S. T. A., \& Walker, L. R. (2015). Is successional research nearing its climax? New approaches for understanding dynamic communities. Functional Ecology, 29(2), 154- 164. https://doi.org/10.1111/1365-2435.12391

Meiners, S. J., Pickett, S. T., \& Cadenasso, M. L. (2015). An integrative approach to successional dynamics. Cambridge, UK: Cambridge University Press.

Moran, E. F., Brondizio, E. S., Tucker, J. M., da Silva-Forsberg, M. C., McCracken, S., \& Falesi, I. (2000). Effects of soil fertility and land-use on forest succession in Amazônia. Forest Ecology and Management, 139(13), 93- 108. https://doi.org/10.1016/S0378-1127(99)00337-0

Niklas, K. J., Midgley, J. J., \& Rand, R. H. (2003). Tree size frequency distributions, plant density, age and community disturbance. Ecology Letters, 6(5), 405- 411. https://doi.org/10.1046/j.14610248.2003.00440.x

Norden, N., Angarita, H. A., Bongers, F., Martínez-Ramos, M., Granzow-de la Cerda, I., van Breugel, M., ... Chazdon, R. L. (2015). Successional dynamics in Neotropical forests are as uncertain as they are predictable. Proceedings of the National Academy of Sciences of the United States of America, 112(26), 8013-8018. https://doi.org/10.1073/pnas.1500403112

Oksanen, J. F., Blanchet, G., Kindt, R., Legendre, P., Minchin, P. R., O'Hara, R. B., ... Wagner, H. (2011). vegan: Community Ecology. R package version 2.0-2.

Parker, V. T., \& Pickett, S. T. A. (1998). Historical contingency and multiple scales of dynamics within plant communities. In D. L. Peterson \& V. T. Parker (Eds.), Ecological scale: Theory and applications (pp. 171- 192). New York, NY: Columbia Press University.

Phillips, J. D. (2004). Divergence, sensitivity, and nonequilibrium in ecosystems. Geographical Analysis, 36(4), 369- 383. https://doi.org/10.1111/j.1538-4632.2004.tb01142.x

Pickett, S. T. A., \& Cadenasso, M. L. (2005). Vegetation dynamics. In E. v. d. Maarel (Ed.), Vegetation ecology (pp. 172-198). Oxford, UK: Blackwell Science.

Pickett, S. T. A., Cadenasso, M. L., \& Bartha, S. (2001). Implications from the Buell-Small Succession Study for vegetation restoration. Applied Vegetation Science, 4(1), 41- 52. https://doi.org/10.1111/i.1654109X.2001.tb00233.x

Pinheiro, J., Bates, D., DebRoy, S., \& Sarkar, D. (2018). nlme: Linear and nonlinear mixed effects models. R package version 3.1-137.

Poorter, L., Bongers, F., Aide, T. M., Almeyda Zambrano, A. M., Balvanera, P., Becknell, J. M., ... Rozendaal, D. M. A. (2016). Biomass resilience of Neotropical secondary forests. Nature, 530(7588), 211- 214. https://doi.org/10.1038/nature16512 
Poorter, L., Jans, L., Bongers, F., \& Van Rompaey, R. S. A. R. (2009). Spatial distribution of gaps along three catenas in the moist forest of Taï National Park, Ivory Coast. Journal of Tropical Ecology, 10(3), 385- 398. https://doi.org/10.1017/S0266467400008063

Powers, J. S., Becknell, J. M., Irving, J., \& Pèrez-Aviles, D. (2009). Diversity and structure of regenerating tropical dry forests in Costa Rica: Geographic patterns and environmental drivers. Forest Ecology and Management, 258(6), 959-970. https://doi.org/10.1016/j.foreco.2008.10.036

Powers, J. S., \& Marín-Spiotta, E. (2017). Ecosystem processes and biogeochemical cycles in secondary tropical forest succession. Annual Review of Ecology, Evolution, and Systematics, 48(1), 497- 519. https://doi.org/10.1146/annurev-ecolsys-110316-022944

Powers, J. S., \& Peréz-Aviles, D. (2013). Edaphic factors are a more important control on surface fine roots than stand age in secondary tropical dry forests. Biotropica, 45(1), 1- 9. https://doi.org/10.1111/j.17447429.2012.00881.x

Reich, P. B., Oleksyn, J., \& Wright, I. J. (2009). Leaf phosphorus influences the photosynthesis-nitrogen relation: A cross-biome analysis of 314 species. Oecologia, 160(2), 207-212. https://doi.org/10.1007/s00442009-1291-3

Riley, S. J., DeGloria, S. D., \& Elliot, R. (1999). A terrain roughness Index that quantifies topographic heterogeneity. Intermountain Journal of Sciences, 5(1-4), 23- 27.

Rudel, T. K. (2012). The human ecology of regrowth in the tropics. Journal of Sustainable Forestry, 31(45), 340- 354. https://doi.org/10.1080/10549811.2011.588457

Sandor, M. E., \& Chazdon, R. L. (2014). Remnant trees affect species composition but not structure of tropical second-growth forest. PLOS ONE, 9(1), e83284. https://doi.org/10.1371/journal.pone.0083284

Santiago-García, R. J., Finegan, B., \& Bosque-Pérez, N. A. (2019). Soil is the main predictor of secondary rain forest estimated aboveground biomass across a Neotropical landscape. Biotropica, 51(1), 10-17. https://doi.org/10.1111/btp.12621

Scatena, F. N., \& Lugo, A. E. (1995). Geomorphology, disturbance, and the soil and vegetation of two subtropical wet steepland watersheds of Puerto Rico. Geomorphology, 13, 199- 213. https://doi.org/10.1016/B9780-444-81867-6.50017-4

Schnitzer, S. A., \& Carson, W. P. (2001). Treefall gaps and the maintenance of species diversity in a tropical forest. Ecology, 82(4), 913-919. https://doi.org/10.1890/0012-9658(2001)082[0913:TGATMO]2.0.CO;2

Schnitzer, S. A., DeWalt, S. J., \& Chave, J. (2006). Censusing and measuring lianas: A quantitative comparison of the common methods. Biotropica, 38(5), 581- 591. https://doi.org/10.1111/j.1744-7429.2006.00187.x

Schnitzer, S. A., Rutishauser, S., \& Aguilar, S. (2008). Supplemental protocol for liana censuses. Forest Ecology and Management, 255(3-4), 1044-1049. https://doi.org/10.1016/j.foreco.2007.10.012

Scholten, T., Goebes, P., Kühn, P., Seitz, S., Assmann, T., Bauhus, J., ... Schmidt, K. (2017). On the combined effect of soil fertility and topography on tree growth in subtropical forest ecosystems-a study from SE China. Journal of Plant Ecology, 10(1), 111- 127. https://doi.org/10.1093/ipe/rtw065

Siddique, I., Vieira, I. C. G., Schmidt, S., Lamb, D., Carvalho, C. J. R., Figueiredo, R. D. O., ... Davidson, E. A. (2010). Nitrogen and phosphorus additions negatively affect tree species diversity in tropical forest regrowth trajectories. Ecology, 91(7), 2121-2131. https://doi.org/10.1890/09-0636.1

Stephenson, N. L., Das, A. J., Condit, R., Russo, S. E., Baker, P. J., Beckman, N. G., ... Zavala, M. A. (2014). Rate of tree carbon accumulation increases continuously with tree size. Nature, 507(7490), 90- 93. https://doi.org/10.1038/nature12914

Tarbox, B. C., Fiestas, C., \& Caughlin, T. T. (2018). Divergent rates of change between tree cover types in a tropical pastoral region. Landscape Ecology, 33(12), 2153- 2167. https://doi.org/10.1007/s10980-018$\underline{0730-0}$

Thomlinson, J. R., Serrano, M. I., Lopez, T. D. M., Aide, T. M., \& Zimmerman, J. K. (1996). Land-use dynamics in a post-agricultural Puerto Rican landscape (19361988). Biotropica, 28(4), 525- 536. https://doi.org/10.2307/2389094

Turner, B. L., Brenes-Arguedas, T., \& Condit, R. (2018). Pervasive phosphorus limitation of tree species but not communities in tropical forests. Nature, 555(7696), 367-370. https://doi.org/10.1038/nature25789 
van Breugel, M., Craven, D., Lai, H. R., Baillon, M., Turner, B. L., \& Hall, J. S. (2019). Soil nutrients and dispersal limitation shape compositional variation in secondary tropical forests across multiple scales. Journal of Ecology, 1-16, https://doi.org/10.1890/0012-9658(2001)082[0913:TGATMO]2.0.CO;210.1111/1365$\underline{2745.13126}$

van Breugel, M., Hall, J. S., Craven, D., Bailon, M., Hernandez, A., Abbene, M., \& van Breugel, P. (2013). Succession of ephemeral secondary forests and their limited role for the conservation of floristic diversity in a human-modified tropical landscape. PLOS ONE, 8(12), e82433. https://doi.org/10.1371/journal.pone.0082433

van Breugel, M., Martínez-Ramos, M., \& Bongers, F. (2006). Community dynamics during early secondary succession in Mexican tropical rain forests. Journal of Tropical Ecology, 22(6), 663- 674. https://doi.org/10.1017/S0266467406003452

Watt, A. S. (1947). Pattern and process in the plant community. Journal of Ecology, 35(1/2), 1- 22. https://doi.org/10.2307/2256497

Werden, L. K., Becknell, J. M., \& Powers, J. S. (2018). Edaphic factors, successional status and functional traits drive habitat associations of trees in naturally regenerating tropical dry forests. Functional Ecology, 32(12), 2766- 2776. https://doi.org/10.1111/1365-2435.13206

Wright, S. J., Kitajima, K., Kraft, N. J. B., Reich, P. B., Wright, I. J., Bunker, D. E., ... Zanne, A. E. (2010). Functional traits and the growth-mortality trade-off in tropical trees. Ecology, 91(12), 3664- 3674. https://doi.org/10.1890/09-2335.1 